\title{
The challenges of e-voting
}

\author{
Ákos Cserny, András Nemeslaki \\ National University of Public Service \\ Ludovika sq. 2. H-1083 Budapest, Hungary \\ DOI:10.13165/VPA-18-17-4-01
}

\begin{abstract}
In our paper we present a research framework, how the concept of evoting, as a complex info-communication technology innovation can potentially create social trust on an institutional level and political cohesion on a national level. In the centre of our argument will be the observation that the fluid borders between citizenship and nationality combined with mobility of inhabitants increase the demand for innovative voting solution supporting national elections. Also by developing this multifaceted research agenda we may find useful theoretical contribution to the field of e-democracy in general.

Keywords: E-Voting, E-Democracy, E-Government, Information and Communications Technology (ICT), Hungary, Central and Eastern Europe (CEE)

Raktiniai žodžiai: e-balsavimas, e-demokratija, e-valdžia, informacinès ir komunikacinès technologijos (IKT), Vengrija, Vidurio ir Rytu Europa (VRE).

\section{Introduction - Conceptual background of e-voting}

E-voting is generally seen as any type of voting that involves electronic means. Although e-voting can be conceived in many different ways, a crucial distinction may be made between electronic machine voting (eMV) and electronic distance voting (eDV). eMV simply refers to the use of any electronic apparatus to record and count votes in a fixed public place. eDV goes a step further in the sense that it implies the electronic registration, culling and counting of votes cast from different locations. It typically allows the voter to use a more generic technology such as interactive digital TV, telephone, Short Message Service (SMS) or the Internet, to cast his vote from any preferred place (Svensson \& Leenes, 2003).
\end{abstract}


In this context we consider that e-voting entails a complex relationship between technology and society (Lee, 2004). E-voting systems are not composed of technology alone; they are systems which emerge from the mutually transformational interactions between information technology and society. The duality of this relationship is essential for understanding how innovation is enabled by information and communications technology (ICT), because information systems are as much the result of ICT enabling society, as much as society enables information systems (Orlikowski, 1992). Furthermore, both the economic value (Brynjolfsson \& Saunders, 2010) and the broader social value (Bannister \& Remenyi, 2003) of such systems depend on how successfully this duality works, and how ICTs and society create new institutionalised socio-technical systems, (Bannister \& Connolly, 2012), (Lips, 2012).

We take the starting point that the design of e-voting system must take the solid basis of security and trustworthiness, and go beyond to understanding voting as a fundamentally social process. As a recent study found, banner messages on a social network about friends who had voted in government elections drove more than 340,000 people to vote. Moreover, studies have indicated that social stimuli can positively affect the quality of decisions made (Vlachokyriakos, Dunphy, Taylor, Comber, \& Olivier, 2013).

\section{Creating "virtual nationality": e-voting as an enabler}

The first dimension of our research proposition for e-voting is the assessment of the desire to vote dimension in two virtual situations - somewhat less addressed fields in Central and Eastern Europe (CEE). The first is to get insights form EU citizenship and its implication on voting, and the second is how opportunities of expatriate or outof-country voting might enhance the impetus on e-voting.

The desire to vote issue: EU and Hungarian parliamentary elections

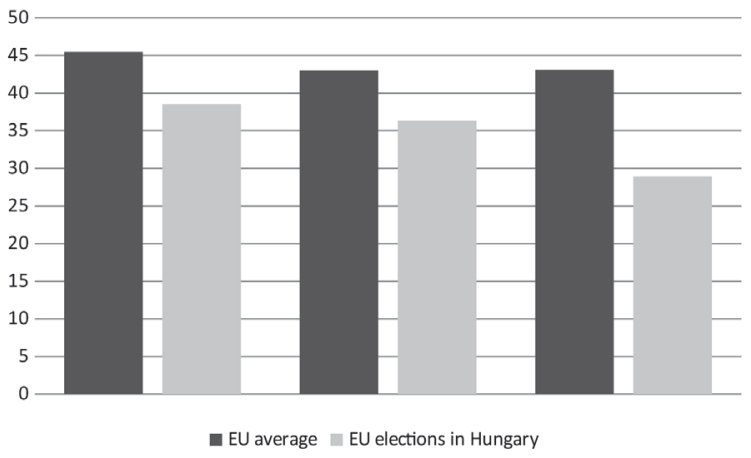

Figure 1. Participation in EU elections. EU average compared to participation in Hungary 
In Figure 1 we show the trends of participation in EU elections on average, and in Hungary. We look at data from 2004 since Hungary's first voting happened after the major EU enlargement in 2004. It is important to note that this enlargement had caused a major decline in voter participation. In 1979 during the first EU (EU-9) parliamentary elections participation was $62 \%$ and it gradually dropped to $45 \%$ (EU-25) in 2004. It is important to note, however, that while EU average participation has stabilized at $41-42 \%$, in Hungary we observe a steady decline, with only few EU member states boasting a lower turnout in EU parliamentary elections than Hungarian citizens (Croatia $-25.2 \%$, Poland $-23 \%$, the Czech Republic - 18\% and Slovakia - 13\%).

Although experts debate weather this trend is continuing or not, the Eurobarometer Research ordered by the EU Commission indicated that in the age group of 15-30 year olds $64 \%$ said that they intended to vote, with $28 \%$ saying that they were absolutely certain to vote and the rest expressing some level of probability (Eurobarometer, 2013).

In the explanation of the results, analysts argue that a young generation of citizens usually participate in voting to a lesser extent than their parents, and they are less and less satisfied how European politics is working. Contrary to this, amongst the youth - under 30 years of age - there is a relatively higher desire to participate, which according to Brussels means they want to have a bigger say in how Europe is working. In Hungary, however, $57 \%$ of young people said they intended to vote in EU elections, with $22 \%$ of them saying they were absolutely certain to vote. Out of the $42 \%$ who reported to abstain from voting $15 \%$ indicated this with certainty compared to the EU average of $11 \%$.

Amongst the non-interested voters $67 \%$ argued that they voting would not mean any significance to the results which is in alignment with the EU-average of $64 \%$. $56 \%$ compared to the EU-average $47 \%$ is simply not interested in politics, and $48 \%$ does not feel equipped well enough to make responsible decision (EU-average 61\%). The seriousness of this latter self-reflection is somewhat confirmed by replying to the test question "Is it true that EP representatives are directly elected by citizens?" 56\% of young people in Hungary replied correctly, compared with the EU-average of $47 \%$ (Eurobarometer, 2013).

One might say, that EU parliamentary elections are so far removed from citizens' real life problems, that intention to vote, and real trust in democratic participation is much relevantly assessed by national elections.

\section{A unique driver for voting: out-of country and expatriate voting}

In our proposed research framework for e-voting capability building we consider the issue of out-of-country and/or expatriate voting an essential opportunity and driving force. Presently, the key technology to involve out-of-country citizens in participating in national elections is via postal voting or personal appearance in foreign representations and consulates. 
This area of national election policy is in the centre of our argument in the case of Hungary for two reasons. Firstly, because the 5 million Hungarians living outside Hungary - 50\% of them basically in neighbouring countries (Slovakia, Ukraine, Romania, Serbia, Croatia, Slovenia and Austria) - are the key focus of national policy especially in providing transparent, non-discriminative and legally satisfactory mechanisms for voting. Secondly, this political strategy might be offsetting the in-country "scepticism" on election participation and also might serve as a test-bed for modernization of electoral institutions in Hungary.

Remote voting is not only a Hungarian issue, by looking at some other relevant data in this context; we see political opportunity in other countries as well. In Table 1 we provide the data of five EU countries in comparison with Hungary, to illustrate the significance of the "virtual citizenship" stream of research in voting capability building. In some of the countries we have found published results of testing e-voting solutions (France and Portugal), and two others reported research endeavours (Italy and Romania).

Table 1. Remote or out-of-country voting in some European countries (Cserny Á. , 2014)

\begin{tabular}{|l|c|c|c|c|c|}
\hline Countries & $\begin{array}{c}\text { Inhabitants } \\
\text { millions }\end{array}$ & $\begin{array}{c}\text { Outside borders } \\
\text { millions }\end{array}$ & $\begin{array}{c}\text { Externally elected } \\
\text { representatives }\end{array}$ & Voting & e-voting \\
\hline France & 66 & 2,5 & $\begin{array}{c}12 \text { senators, } \\
11 \text { representatives }\end{array}$ & postal & tested \\
\hline Portugal & 10,5 & 5 & 4 representatives & postal & tested \\
\hline Italy & 61 & 4,2 & $\begin{array}{c}6 \text { senators, } \\
12 \text { representatives }\end{array}$ & postal & researched \\
\hline Croatia & 4,3 & 1,7 & $\begin{array}{r}3 \text { representatives } \\
2 \text { senators, } \\
4 \text { representatives }\end{array}$ & personal & researched \\
\hline Romania & 23 & 4,2 & national list vote & postal & - \\
\hline Hungary & 10 & 5 & &
\end{tabular}

With further exploration and agenda setting in this research direction we intend to gain higher impetus for e-voting implementation in the political dimensions and stakeholder support.

\section{Creating security awareness: foundation of e-voting}

In the technical dimensions one of the ultimate key success factors of e-voting implementation is security. This entails cryptographic coding of votes, secure identifications, reliable data transfer and many more technical details for maintaining trust in voters, electoral institutions and political parties. The main problem, which we 
intend to turn into an opportunity in this second research area, is that security issues have become systemic, social and highly impacting legal establishments in the area of government operations. Protecting electronic data assets and critical information infrastructure has become a crucial issue worldwide.

In this section we develop arguments that e-voting capability can be built from developing the interdisciplinary concepts and solutions of information security, especially when they provide a comprehensive approach for treating ICT management in the public sectors. Using Hungary's case this proposition might serve as a driver for e-voting.

The more developed e-Government systems we have and the more activities are conducted in the "cyberspace", the more exposed they are to high level of risks: attack against multiple systems or against a full infrastructure. This can be a conventional crime, as cybercrime, or may be an unconventional event, called cyberterrorist attack. The term "cyberspace" emphasizes the close relationship between "complex networks", relationships between individuals, institutions, ICT, and social networks; in contrast to the earlier concept of "computer network" which has had primarily a technical meaning. According to Benjamin Netanyahu "Terrorism is the deliberate and systematic murder, maiming, and menacing of the innocent to inspire fear for political ends." (Netanjahu, 1995, p.: 20). The U.S. Federal Bureau of Investigation defines cyberterrorism is any "premeditated, politically motivated attack against information, computer systems, computer programs, and data which results in violence against non-combatant targets by sub-national groups or clandestine agents." (Tiefenbrun, 2002)

As Krasznay and Török writes governments must maintain countermeasures against the following cyberthreats (Krasznay \& Török, 2014):

- Cybercrime: organized crime which is deeply involved in the cyberspace. Cybercrime acts can have negative side effects to all governmental institutes and public servants. These types of crimes can be intertwined with other cyberthreats as well.

- Cyberterrorism/hacktivism: Hacktivist activities usually target governmental institutes. Cyberterrorists use the same toolset as hacktivists do with very similar goals. That is why governments need to handle both issues with similar countermeasures.

- Cyberespionage: When most of our information is handled electronically, intelligence services start focusing more intensively on cyberspace. All governments must consider this threat and try to prevent data leaks.

- Cyberwarfare: Cyberspace is the new battlefield and in this battlefield governmental IT is a major target. In some extreme situations governments must pay extremely high attention to this new "coding warfare".

Since 2012, Hungary has been building a systematic strategy, legal codification and awareness campaign in the area of cyber security, which might be used as a 
trust-building technical foundation for further e-Government development, such as e-voting (Szádeczky, 2014).

\section{Creating e-Government: from e-participation to e-voting}

For developing the third stream of drivers to develop our research agenda for evoting we refer to the findings articulated by several authors in the field that e-voting capabilities in a country are very much determined by broader experiences with public ICT implementations, particularly emphasized by (Avgerou, 2013) and (Prosser \& Krimmer, 2004).

In order to compare the ICT adoption situation in Hungary compared to other countries relevant from external voting point of view, we collected the most recent data on e-Government usage and development in Table 2. The first eight countries are Hungary's neighbourghs and the others are ranked in order of the number of external voters registered in the particular country. With this ranking we intended to consider, that citizens behaviour and attitude toward e-Government is determined by their living environment, so we might expect more positive adoption behaviour in higher ranked countries, no matter how developed Hungary is in this respect. For instance, in Table 2 we can observe that Hungary has higher ranking than its neighbours with the exemption of Austria, but has a definite lag behind non-neighbourgh EU and non-EU countries which might create tensions in citizens' behaviour using e-voting technologies. It is especially interesting if we look at the e-Participation Index in Table 2 where we see an even more diverse picture.

To get more insights into how government transparency is assessed by citizens, we compiled further data in Table 3 from the e-Government Benchmark Survey to compare the same countries from the points of service, public organizations and personal data scoring (European Commission, 2013). The report which examined the usage of 19 public administration services, states that the Hungarian data of use are almost 41 percent lower than the European average, Hungary took the 30th of the 32 places in the European ranking. The rate of those trusting and regularly using e-Government services is 6 percent lower than the average of the EU members (32 percent), while the proportion of those preferring offline administrations is 11 percent higher than the Union average (38 percent).

What we can see from Table 3 is that in most countries external voters trust in government transparency is lower than the EU average, so development will be essential to enhance trust in e-voting. For instance in Romania, which is the most significant from this point of view we have a score of 6 on service transparency and 0 on personal data, which offer major rooms to improve compared to the EU-averages of 41 and 43 respectively. On the other hand, countries such as Austria, Belgium and Spain might serve as potential e-voting experiments due to their high citizen trust in government transparency. 


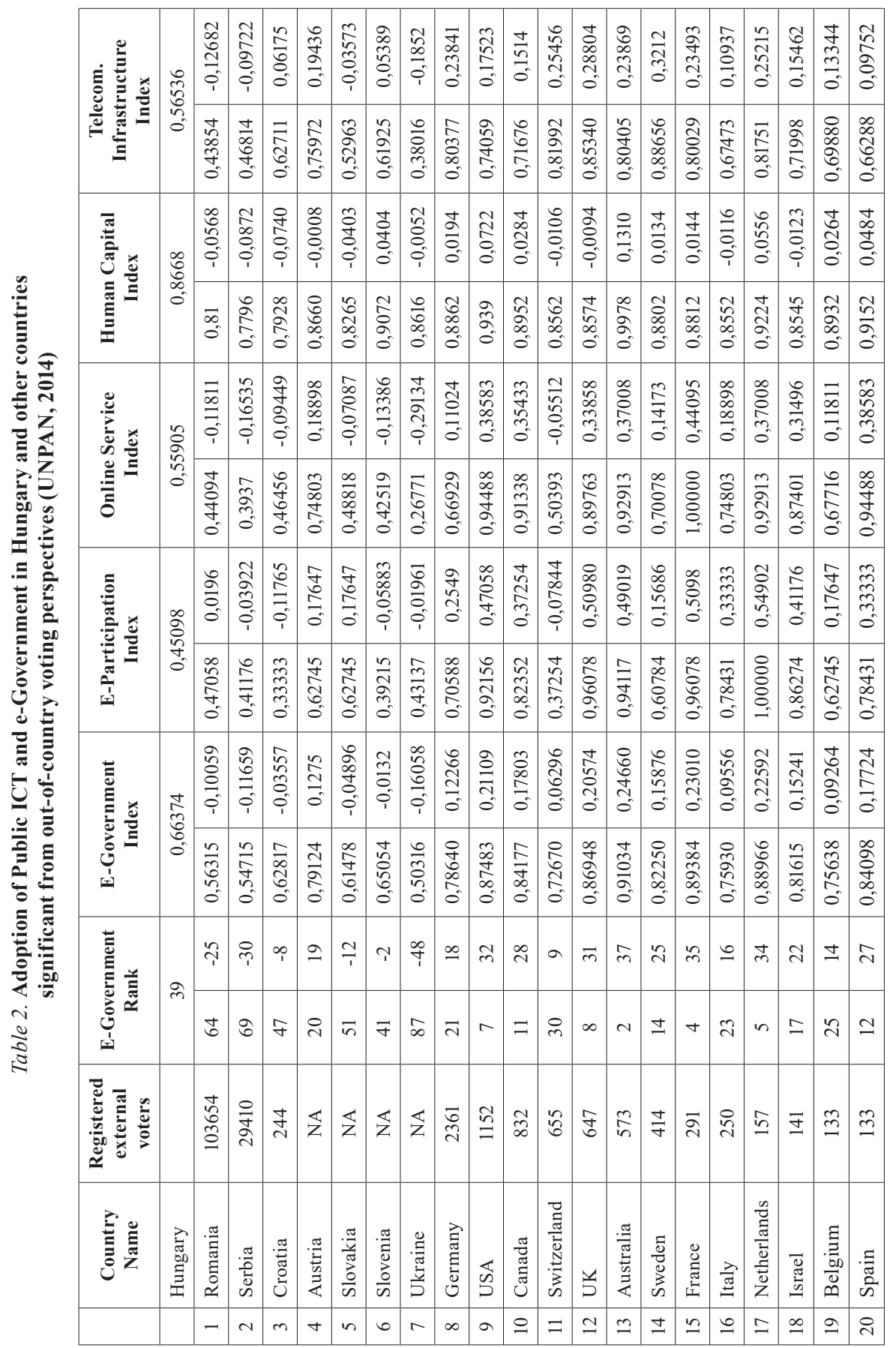


Table 3. Government transparency from user perspective in countries significant from out-of-country voting perspectives (European Commission, 2013)

\begin{tabular}{|c|c|c|c|c|c|}
\hline & Country Name & $\begin{array}{c}\text { Registered external } \\
\text { voters }\end{array}$ & $\begin{array}{l}\text { Service } \\
\text { delivery }\end{array}$ & $\begin{array}{l}\text { Public organi- } \\
\text { zations }\end{array}$ & $\begin{array}{c}\text { Personal } \\
\text { data }\end{array}$ \\
\hline & Hungary & & 28 & 32 & 17 \\
\hline 1 & Romania & 103654 & 6 & 48 & 0 \\
\hline 2 & Serbia & 29410 & NA & NA & NA \\
\hline 3 & Croatia & 244 & 33 & 56 & 56 \\
\hline 4 & Austria & NA & 53 & 80 & 75 \\
\hline 5 & Slovakia & NA & 4 & 44 & 0 \\
\hline 6 & Slovenia & NA & 60 & 90 & 78 \\
\hline 7 & Ukraine & NA & NA & NA & NA \\
\hline 8 & Germany & 2361 & 31 & 57 & 33 \\
\hline 9 & USA & 1152 & NA & NA & NA \\
\hline 10 & Canada & 832 & NA & NA & NA \\
\hline 11 & Switzerland & 655 & 12 & 74 & 6 \\
\hline 12 & UK & 647 & 32 & 48 & 31 \\
\hline 13 & Australia & 573 & NA & NA & NA \\
\hline 14 & Sweden & 414 & 53 & 70 & 86 \\
\hline 15 & France & 291 & 40 & 50 & 75 \\
\hline 16 & Italy & 250 & 18 & 56 & 33 \\
\hline 17 & Netherlands & 157 & 56 & 76 & 67 \\
\hline 18 & Israel & 141 & NA & NA & NA \\
\hline 19 & Belgium & 133 & 58 & 72 & 25 \\
\hline \multirow[t]{2}{*}{20} & Spain & 133 & 86 & 82 & 78 \\
\hline & EU 27 average & & 41 & 66 & 43 \\
\hline
\end{tabular}

\section{Creating trust in institutions: social construction of e-voting}

As Julie Freeman and Sharna Quirke has phrased, digital democracy, e-participation, and greater civic engagement have subsequently been labelled myths of eGovernment; unlikely to occur without broader changes in the culture of government to be more open, receptive and responsive to civic views (Freeman \& Quirke, 2013, p.: 31). They argue that most governments - like also the governments of Hungary - have placed little emphasis on the development of online practices that enable civic contributions to impact decision-making, instead prioritised information dissemination and service delivery features, that is they placed the integrative and efficiency orientation of e-Government in the centre of development strategies. 
This is understandable from the point that e-voting socio-technical solutions require high level of e-democracy maturity, or at least this assumption has been rather dominant in European research efforts such as the STOA Workshops (STOA, 2011). Also Mulder and Hartog suggests that e-democracy has a certain value chain with elements systematically built upon each other (Mulder \& Hartog, 2013). They argue that the e-democracy value chain has to be building up as the following sequence (Mulder \& Hartog, 2013, p.: 27):

- Being informed is an essential requirement that allows citizens to know what is going on and communicate their opinion.

- Deliberating provides the ability to engage in structured dialogue and reflection leading to insight and conclusions.

- Valuing the results of the dialogue would allow for identifying and prioritization the issues that need attention.

- Decision making is a distinct process allowing the development of structured argumentation and solution formulation.

- Voting allows participants to finally converge on a single political outcome.

Consequently, as a fourth driver of our research agenda we propose the exploration of the social mechanisms of how trust is built up in the "e-democracy valuechain", and to find the connections of different institutional and emergent elements of how structuration of trust occurs and is enhanced by technology.

Earlier, at the desire-to-vote section we showed that behaviour of younger generation is a key factor in how democratic institutions of elections perform, and that the final political aim of ICT enhanced elections - social structuration in this context - is to create a sustainable interplay between institutions and voters behaviour.

In the case of Hungarian young voters compared to the European average, their contribution to political democracy through voting is considered much less effective (Eurobarometer, 2013). Promising directions as we see in Figure 2 are relatively higher social sensitivity and willingness to join NGOs and associations in the public sphere.

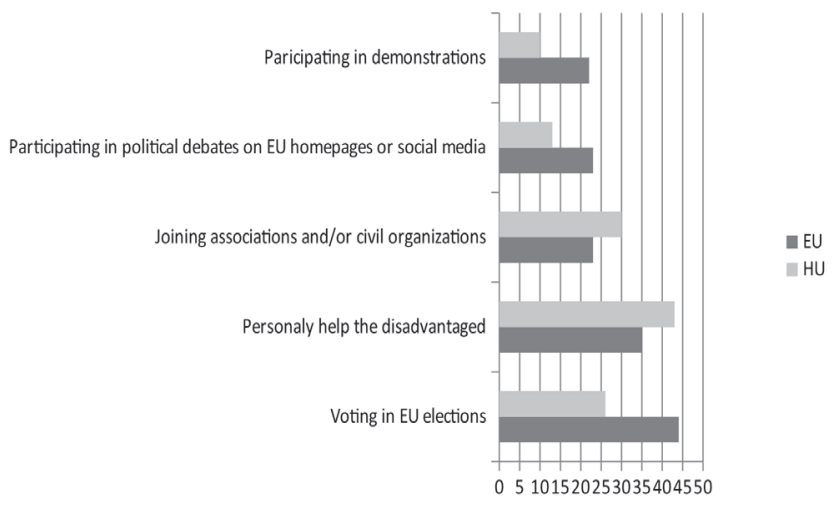

Figure 2. Which is the best way for you to effectively participate in EU public debates? (\% of respondents) (Eurobarometer, 2013) 
In alignment the Eurobarometer finding, recent Hungarian empirical studies have alarming results about the declining trust in public participation and trust in institutions (Székely, 2013). Practically, the findings of the research show that there is not one single institution in Hungary which would enjoy the trust of the 15-29 generation, only the military, police and court system was scored on the positive range of the trust scale. $19 \%$ of this generation reported that they were absolutely certain to vote. The Hungarian Youth - 2012 research project also found that interest of all educated social groups has declined in politics $-57 \%$ of respondents indicated that they are not paying attention under any circumstances to politics (Székely, 2013). Earlier in the same research in $200834 \%$ reported that they were absolutely certain to vote and less than $9 \%$ replied that they were definitely not going to vote (16\%) in 2008 .

Since 2008 a drastic decline can be observed in the perceived trust in the Constitutional Court and President of the Republic, but also growing negative perception about economic institutions such as banks for instance. Young Hungarians have such a low level of trust in democratic institutions, that only $40 \%$ of them considers democracy as the best possible political system, and - although most of them never lived at the time - nurture nostalgic ideas about the "goulash communism" of Hungary (Székely, 2013).

In the context of social confidence in democratic institutions is important to record that the legitimacy of the elections, as basic legitimacy on the exercise of power as a priority in terms of the functioning of the state. Therefore the new electronic forms of voting today basically legality, legitimacy problem occurs.

Creating and restoring trust in democratic institution and the enhancement of social construction of the e-democracy value-chain seems to be the most critical factor of e-voting experiments in Hungary and CEE.

\section{Conclusions}

In this research agenda paper we propose five directions for e-voting development in the Hungarian and broader CEE context based on a conceptual review of the topic and some empirical data and observations.

1. Firstly, we identified the relevance and opportunity in the CEE region of the "virtual nationality" concept both in the EU context and in trans-national settings. Increasing national cohesion for out-of-country citizens might serve as a driver and essential political motivator for e-voting experiments even in less "participatory" countries.

2. Secondly, building e-voting programmes on comprehensive cybersecurity foundations also might indicate more likely institutional trust building especially in the technical mechanisms of the electronic voting processes. Comprehensiveness in this context covers coordinated technical, legal and educational approach to information security with a potentially wide spill 
over impact in security awareness which opens up doors for e-voting development

3. Thirdly, we argued that creating and enhancing e-Government solutions gradually increase participation which in return increases willingness to technology adoption. Given the fact, that e-voting is on the top of e-participation maturity chain, building up the level of ICT adoption and use, both on the institutional and citizen side, contributes to a more astute and innovative social environment. We argued that out-of-country voting might be a special driver in this context when a country extends e-voting to a more e-participative country than its home base.

4. Fourthly, with the illustration of sociological research amongst youth in Europe and Hungary we proposed an intensive stream of constructivist inquiry how trust can be built in democratic institutions via technology and how electoral organizations can be won to embrace the idea of e-voting initiations. In our context of Hungary, and in CEE, this is a critical element of any future development in e-voting since there are deeply rooted social barriers which hinder technology deployments for enhancing democratic participation.

5. In conclusion, we offer our arguments not only to the Hungarian and CEE context, so that the fictitious e-voting future could be brought closer to reality, but by developing this multifaceted research scheme we may also find useful theoretical contribution to the field of e-democracy in general.

\section{BIBLIOGRAPHY}

1. Avgerou, C. (2013). Explaining Trust in IT-Mediated Elections: A Case Study of E-Voting in Brazil. Journal of the Association for Information Systems , 14 (8), 420-451.

2. Bannister, F., \& Connolly, R. (2012). Forward to the past: Lessons for the future of egovernment from the story so far. Information Polity, 17 (3-4), 211-226.

3. Bannister, F., \& Remenyi, D. (2003). The Societal Value of ICT - First Steps Towards an Evaluation Framework. Electronic Journal of Information Systems Evaluation , 6 (2), 197-206.

4. Brynjolfsson, E., \& Saunders, A. (2010). Wired for Innovation: How Information Technology is Reshaping the Economy. Cambridge, Massachusetts: MIT Press.

5. Cserny, Á. (2014): Thoughts on issues of foreign citizens in the exercise of voting rights. In: Cserny, Á. (ed.): Boundless elections. Studies the election of the topic of citizens living abroad. National University of Public Servise. Election Systems Research Workshop. Budapest. 27-39.

6. Eurobarometer. (2013). One Year To Go To The 2014 European Elections: Analytical Overview (EB/EP 79.5). Brussels: Directorate-General for Communication, Public Opinion Monitoring Unit. 
7. European Commission. (2013). Public Services Online 'Digital by default, or by Detour?' Assessing User Centric eGovernment performance in Europe - 2012 Benchmark. Luxemoburg: Publications Office of the European Union.

8. Freeman, J., \& Quirke, S. (2013). Is E--democracy a Myth Civic Participation and Democratic Reform. In P. Praycek, \& N. Edelmann, CEDEM 13: Proceedings of the International Conference for E-Democracy and Open Government (2nd edition.). Austria: Danube Krems University. 31-43.

9. Krasznay, C., \& Török, S. (2014). Hungary's Cyber Defense Readiness from the Perspective of International Recommendations. Hadmérnök (Military Engineering) (1), 209-216.

10. Lee, A. (2004). Thinking about Social Theory and Philosophy for Information Systems. In J. Mingers, \& L. Willcocks, Social Theory and Philosophy for Information Systems. Chichester, England: John Wiley \& Sons. 1-26.

11. Lips, M. (2012). E-Government is dead: Long live Public Administration 2.0. Information Polity, 17 (3-4), 239-250.

12. Mulder, B., \& Hartog, M. (2013). Applied E-democracy - A need for an information framework to support development. In P. Praycek, \& N. Edelmann, CEDEM 13: Proceedings of the International Conference for E-Democracy and Open Government (2nd edition.) Austria: Danube Krems University. 19-30.

13. Netanjahu, B. (1995). Harc a terrorizmus ellen (Fight Against Terrorism). Budapest: Alexandra.

14. Orlikowski, W. (1992). The duality of technology: Rethinking the concept of technology in organizations. Organization Science , 3 (3), 398-427.

15. Prosser, A., \& Krimmer, R. (2004). The dimensions of electronic voting. In A. Prosser, \& R. Krimmer, Electronic Voting in Europe - Technology, Law, Politics and Society. Austria, Germany, Switzerland: GI and OCG. 21-28.

16. STOA. (2011). Can e-Voting Increase Electoral Participation? Brussels: STOA Workshop at the European Parlament 2011. March 17.

17. Svensson, J., \& Leenes, R. (2003). E-voting in Europe: Divergent democratic practice. Information Polity, 8 (1/2), 3-15.

18. Szádeczky, T. (2014). Information Security - Strategy, codification and awareness. In A. Nemeslaki, ICT Driven Public Service Innovation. Budapest: National University of Public Service. 99-112.

19. Székely, L. (2013). Hungarian Youth 2012 - Research Report (in Hungarian). Budapest: Kutatópont.

20. Tiefenbrun, S. (2002). A semiotic approach to a legal definition of terrorism. ILSA J. Int'l \& Comp., 371.

21. UNPAN. (2014). United Nations E-Government Survey 2014: E-Government for the Future we Want. New-York: United Nations Department of Economic and Social Affairs.

22. Vlachokyriakos, V., Dunphy, P., Taylor, N., Comber, R., \& Olivier, P. (2013). Unpicking the desing space of e-voting for Participation. In P. Praycek, \& N. Edelmann, CEDEM 13: Proceedings of the International Conference for E-Democracy and Open Government (2nd edition) Austria: Danube Krems University. 357-362. 


\section{Ákos Cserny, András Nemeslaki \\ E-balsavimo iššūkiai}

Anotacija

Šiame darbe pristatoma e-balsavimo, kaip sudètingos informacinių ir komunikacinių technologijų naujovių koncepcijos, kuri gali potencialiai sukurti socialinị pasitikèjimą instituciniu lygmeniu ir politinę sanglaudą nacionalinių lygmeniu, mokslinių tyrimų sistema. Mūsų pagrindinis argumentas - pastebejjimas, kad sklandžios ribos tarp pilietybès ir tautybės kartu su gyventojų mobilumu didina inovatyvaus balsavimo sprendimo, palaikančio nacionalinius rinkimus, paklausą. Be to, plètodami šią daugialypę mokslinių tyrimų darbotvarkę, galime plèsti ir bendrą naudingą teorinị indèlị ị e-demokratiją.

András Nemeslaki - Nacionalinio viešojo administravimo universiteto Viešojo administravimo fakulteto profesorius, Vengrija. El. paštas: nemeslaki@finance.bme.hu

András Nemeslaki - professor, National University of Public Service, Faculty of Public Administration, Hungary

El. paštas: nemeslaki@finance.bme.hu

Ákos Cserny - Nacionalinio viešojo administravimo universiteto Viešojo administravimo fakulteto docentas, Vengrija.

El. paštas: drcserny@gmail.hu

András Nemeslaki - Nacionalinio viešojo administravimo universiteto Viešojo administravimo fakulteto profesorius, Vengrija.

El. paštas: nemeslaki@finance.bme.hu 